\title{
DISCRIMINATION AGAINST MIGRANT WORKERS IN MALAYSIA*
}

\author{
Zainal A. Ayub ${ }^{* *}$, Zuryati M. Yusoff ${ }^{* * *}$, Harlida A.Wahab ${ }^{* * * *}$, \\ Muhammad H. Badarulzaman******
}

Labour Law, School of Law Universiti Utara Malaysia

UUM-COLGIS, 06010 UUM Sintok, Kedah, Malaysia

\section{Abstract}

Migrant workers are often discriminated in almost every aspect of life. Using doctrinal research methodology, this article discusses direct and perceptive discrimination against them. This article concludes that physical discriminations are mostly happened because ineffective enforcement of the law, abuse of powers and human-trafficking problem. Besides, perceptive discrimination happened due to the claim that migrant workers contribute to the crimes hike in Malaysia whereas it is unsupported based on statistic given by The Royal Malaysian Police.

Key words: discrimination, migrant workers, crime rate.

\section{Intisari}

Diskriminasi terhadap pekerja migran di Malaysia berlaku hampir dalam setiap aspek kehidupan mereka. Penelitian ini dilakukan melalui metode penelitian doktrinal dan membicarakan mengenai diskriminasi secara langsung (fisik) dan diskriminasi berdasar persepsi terhadap golongan migran. Kesimpulannya adalah diskriminasi secara langsung terjadi karena ketidakefektifan undang-undang, relasi kuasa dan perdagangan manusia. Sedangkan diskriminasi berdasar persepsi terjadi karena adanya klaim bahwa pekerja migran menyebabkan peningkatan jinayah padahal hal ini tidak didukung oleh data dari Royal Malaysian Police.

Kata Kunci: diskriminasi, pekerja migran, tingkat jinayah.

\section{Pokok Muatan}

A. Background 557

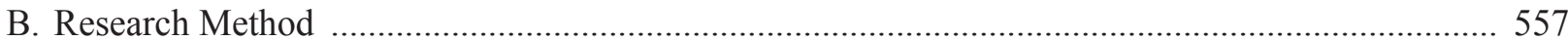

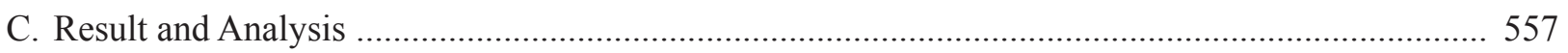

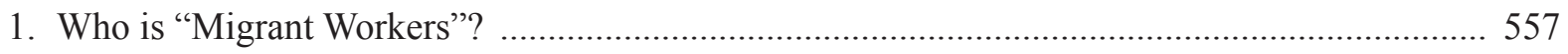

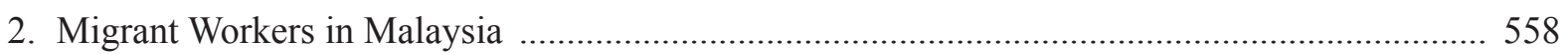

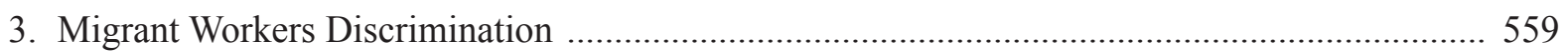

4. Direct Discrimination-Mistreatment Against Migrant Workers ............................................... 559

5. Perceptive Discrimination- Crimes Hike and Migrant Workers in Malaysia ............................... 562

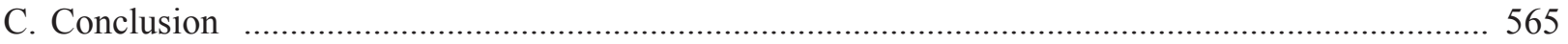

\footnotetext{
Research of School of Law Universiti Utara Malaysia.

Correspondence address: z.amin@uum.edu.my.

*** Correspondence adress : zuryati@uum.edu.my.

***** Correspondence adress : harlida@uum.edu.my.

***** Correspondence adress : mdhafiz@uum.edu.my.
} 


\section{A. Background}

Migrants are the faction of population who are often discriminated against in almost every aspect like education, housing, work, health and social security. According to United Nations (UN), there are $3.1 \%$ of the world population that is around 200 million people live outside their countries of origin, and they are subjected to xenophobia, or the fear of foreigners, ${ }^{1}$ which becomes the main source of racism. The declaration in Durban, South Africa or better known as "Durban Declaration" acknowledges the discrimination against migrants as a global problem. ${ }^{2}$ Due to insensitivity of many people, even legal immigrants are facing discrimination the problem of harassment and discrimination. ${ }^{3}$

Discrimination rooted in human civilisation since immemorial. It may come in forms of racial discrimination, age discrimination, gender discrimination, religious or beliefs discrimination, sex and sexual orientation, pregnancy, disability or even marriage discrimination. Discrimination against migrant workers is not only intense and irrational dislike of them, but also negative perception of them. More often than not, there is a "myth" that the influx of migrant workers will always relate to the rise of crime rate. As stated by Bianchi, Buonanno and Pinotti, migration has always been a contentious issue in countries for at least two reasons ${ }^{4}$. The first is in relation to the great number labour workforce compared to the population. Second, the increase of crime rates with the increase of migrant workers. This article provides an insight into the significant issue of discriminations relating to migrant workers in Malaysia.

Based on the above, this article highlights the problem of discrimination against migrant workers which is under "direct discrimination" and "perceived discrimination" against migrant workers in Malaysia. It mainly explores the plight of the migrant workers and seeks the truth of the contention that crime hikes (in Malaysia) are due to the growing numbers of migrant workers.

\section{B. Research Method}

This article adopts doctrinal research methodology. Doctrinal research is a study of legal and practice doctrines and is largely documentary. According to Salter and Mason, doctrinal research methodology is a study that focuses on the cases, rules and principles. These cases, rules and principles comprise of substantive content of legal doctrine. Deploying a deductive form of legal reasoning from legal principles is a classic form of doctrinal research method. ${ }^{5}$ In other words, doctrinal research is a research which defines what the law in a particular area is. In doing so, the researcher collects and analyses the data from the primary and secondary sources. ${ }^{6}$ Doctrinal research is mainly a library-based research. In the doctrinal approach, the sources of the research data are primary, secondary and tertiary. The primary data is collected by way of reference to statutes and decided law cases. Secondary data is taken from textbooks, journals, commentaries and articles. The third level of data is tertiary data. It is collected from the Internet. This data is similar to newspapers and websites which are easily accessible from office or home computers.

\section{Result and Analysis \\ 1. Who is "Migrant Workers"?}

The term "migrant" has been defined by

Catherine Tactaquin, "Immigration and Globalization: The UN Conference Against Racism Takes on Migrant Issues", http://www.corpwatch. org/article.php?id=375, accessed on 20 April 2014.

The United Nations, "United Nations Human Rights: Combating Discrimination against Migrants", http://www.ohchrorg/EN/Issues/ Discrimination/Pages/discrimination_migrants.aspx, accessed on 20 April 2014.

Ali Soylu and Tom A. Buchanan, "Ethnic and Racial Discrimination Against Immigrants", Journal of Business and Economics, Vol. 4, No. 9 , 2013, p. 848.

4 Milo Bianchi, Paolo Buonanno, and Paolo Pinotti. "Do Immigrants Cause Crime?" Journal of the European Economic Association Vol.10, Issue. 6, 2012, p. 1318

5 Michael Salter and Julie Mason, 2007, Writing Law Dissertations: An Introduction and Guide to The Conduct of Legal Research, Pearson Education, London, p. 45.

6 Ian Dobinson and Francis Johns, 2007, Qualitative legal research, Edinburgh University Press, Edinburgh, p. 19. 
United Nation as a migrant as "anyone who changes his or her country of usual residence for at least a year". As for "migrant workers", they are the migrant who changes his or her country of usual residence for the purpose of working. In other words, it is internationally accepted that a migrant worker refers to anyone who enters or leave his or her country for work. This also includes their family, dependants, asylum seekers and even students. ${ }^{7}$ Though "migrants" and "immigrants" should not be used interchangeably, immigrant, legal or illegal, also includes in the terms of "migrants" since immigrant is a citizen of a country who enters another country with the intention to set up permanent residence at the country he enters. ${ }^{8}$

In the context of this article, the UN definition of "migrant" is adopted and used throughout the article. As shown in Figure 1, Malaysia has the total population of 28 million whereby there are eight percent of non-citizens population in Malaysia of which the migrant workers form the largest number of the population.

\section{Chart 1. Distribution of Population in Malaysia}

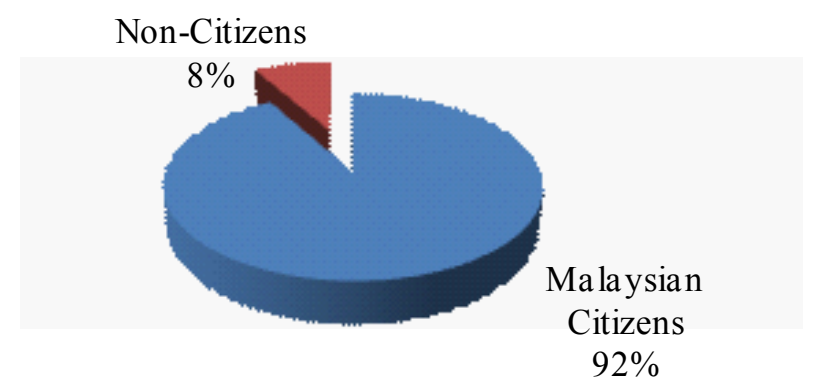

Source: Malaysian Department of Statistics, Census 2010.

\section{Migrant Workers in Malaysia}

The presence of migrant workers in Malaysia initially started during the colonial period in the $19^{\text {th }}$ century when foreign workers were brought in to Malaysia particularly from India and China as labours in rubber estates and mines. ${ }^{9}$ There are several reasons for the influx of migrant workers to Malaysia but the main force is the dynamic of Malaysian economy. Previously, Malaysia was regarded as one the 'Asian Tiger of Economy' before the economic turmoil in $1998 .{ }^{10}$ After the economic downturn in Asia in 1998, Malaysia still going strong and quickly recovered and this has attracted millions of workers around the region to Malaysia. Two main factors that attracting migrant workers to Malaysia are: ${ }^{11}$ (i) Malaysia offers higher wages and opportunities compared to their home state; and (ii) there is a lot of opportunity for foreign workers to work in the 3D jobs (dangerous, dirty, difficult) in the construction sectors, agricultural, plantation and manufacturing.

In general, the migrant workers who come to Malaysia seek for employment. They are mainly labour migrants who are largely low-skilled workers. The significant stages of the coming of the workers were in the 1970s, early 1980s and late 1980's. The rural plantation sector contributed the most migrant workers influx to Malaysia in the 1970's. Then, the needs grew in the agricultural and construction sectors in the late 1970's and early 1980's. In late 1980 's, the demand for labours in Malaysia reached its peak when Malaysia experienced high economic growth. ${ }^{12}$ The exponential growth of Malaysian economy caused a large numbers of both legal and illegal migrant workers. Then, the coming of

Migration Watch United Kingdom, "How Immigration is Measured”, http://www.migrationwatchuk.org/briefingPaper/document/95, accessed on 13 June 2014

8 Immigration Assist declares that "An Immigrant is a person who has citizenship in one country but who enters a different country to set up a permanent residence. Just entering another country does not make you an immigrant." See Imigration Assist United Kingdom, "What is An Immigrant", http://www.immigrationassist.co.uk/immigration/what-is-an-immigrant/, accessed on 20 April 2014.

9 Nicola Piper, "Migrant Labor in Southeast Asia", http://www.fes.de/aktuell/focus_interkulturelles/focus_1/documents/8_000.pdf, accessed on 13 June 2014

10 Ngai Weng Chan, et al., "Integrating Official And Traditional Flood Hazard Management In Malaysia", http://eprints.usm.my/1198/1/ Integrating_Official_And_Traditional_Flood_Hazard_management_In_Malaysia.pdf, accessed on 13 June 2014.

11 P. Iruthayaraj D Pappusamy, "Impact of Foreign Labour on Industry", in Cyrus Das, Employment and Industrial Relations Law in Malaysia, 2014, CLJ Publication, Ampang, p. 10.

12 Milo Bianchi, et al., Loc. cit. 
the migrant workers to Malaysia stabilise due to Malaysia's economic downturn. Apart from that, Malaysia started to impose severe penalties for illegal entry and illegal employment which also slow down the influx of migrant workers into Malaysia.

With regards to the number of the migrants in Malaysia, the estimation is between 2 million to 4 million people. They fall under the "non-citizen" category that forms $8 \%$ out of all Malaysian population as shown in Figure 1 above. Out of this number, about 2.2 million are registered migrant workers, and about the same number are unregistered (i.e. undocumented or irregular) workers. ${ }^{13}$ Indonesia is the main contributor to these number migrant workers, as well as other countries like Nepal and Bangladesh. Besides, Malaysia also attracted large number workers from Myanmar and Cambodia in recent years. Also, a small number of migrant workers contributed to the statistics are workers from Vietnam, India, Philippines, Pakistan, Thailand, China, and Sri Lanka. ${ }^{14}$

\section{Migrant Workers Discrimination}

As mentioned earlier, migrant workers all over the world are facing discrimination almost in every aspect of their life, including education, housing, work, health and social security. ${ }^{15}$ It has been reported that in Malaysia, the non-citizens suffer discrimination in respect of their fundamental rights, which includes violence, discriminatory detention and deportation, lack of access to justice, deprivation of family life, limited or non-existent of health care, education and housing. ${ }^{16}$ However, the discrimination against the migrant workers in this article will only be in the context of domestic workers, forced labour and human trafficking, which are almost interconnected. As reported by the Equal Rights Trust, "the conditions of migrant workers often amount to forced labour. Many become the victims of human trafficking and have been recruited by fraud or deception for purposes of exploitation". ${ }^{17}$

The Declaration of Principles on Equality by the Equal Rights Trust, London offers, among others, the following definition of discrimination:

"Discrimination based on any other ground must be prohibited where such discrimination (i) causes or perpetuates systemic disadvantage; (ii) undermines human dignity; or (iii) adversely affects the equal enjoyment of a person's rights and freedoms in a serious manner $[\ldots] " .{ }^{18}$

Hence, the authors are only highlighting two significant issues: firstly, the mistreatment or abuse against migrant workers (that may relate to points (i) and (ii) of the Declaration); and secondly, the discrimination with regards to negative perception towards migrant workers in relations to the crime index (which may be associated with point (iii) above).

\section{Direct Discrimination-Mistreatment Against Migrant Workers}

The mistreatment of migrant workers may be classified as "direct discrimination". The direct discrimination against migrant workers may lead to physical mistreatment and abuse. The mistreatment against migrant workers in Malaysia may well be directed at the problems of domestic workers, forced labour and human trafficking. Unfortunately, there is no official statistics on the number of cases on mistreatment against migrant workers in Malaysia, which is actually also a form of 'indirect discrimination' against them. Besides, the direct discrimination i.e. mistreatment against migrant workers are also done by the enforcement and recruitment agencies when they are dealing with

13 Amnesty International, 2010, Trapped: The Exploitation of Migrant Workers in Malaysia, Amnesty International Publication, London, p. 15.

14 Ximena Del Carpio, et.al., "Immigration in Malaysia: Assessment of its Economic Effects, and a Review of The Policy and System", http:// psu.um.edu.my/images/psu/doc/Recommended\%20Reading/Immigration\%20in\%20Malaysia.pdf, accessed on 13 June 2014.

15 The United Nations. United Nations Human Rights: Combating Discrimination against Migrants, http://www.ohchrorg/EN/Issues/ Discrimination/Pages/discrimination_migrants.aspx, accessed on 12 June 2014.

16 The Equal Rights Trust, "Washing the Tigers - Addressing Discrimination and Inequality in Malaysia", http://www.equalrightstrust.org/ ertdocumentbank/Malaysia\%20CR\%201.pdf, accessed on 13 June 2014

17 Ibid.

18 Principle 5 The Declaration of Principles on Equality. See Ibid. 
migrant workers.

\section{a. Domestic Workers and Forced Labour}

Domestic workers make up the majority of Malaysia's migrant workers. ${ }^{19}$ The main problem in regards to domestic workers is the abuse and mistreatment by the employer. They are often subjected to physical and sexual abuse including rape; while some of them had been beaten, sexually assaulted, and subjected to other forms of inhuman and degrading treatment such as being burnt with cigarettes and hot iron. ${ }^{20}$ Though the number of cases reported is considered small as most employers are reasonable, there are instances where some of them are cruel and acted inhumanely towards the domestic workers. For example, in Yim Pek Ha v. Public Prosecutor $^{21}$, the employer was charged with four counts of causing grievous hurts and was sentenced 12 years jail term. Yim Pek Ha, who was the employer, scalded the maid, Nirmala Bonat, with both hot water and iron. She was beaten and burned for her mistakes during the 5 months she worked in Yim's house which causing her suffered pain, humiliation, physical and mental anguish while working with the employer. The court also ordered her employer to pay general and special damages for personal injury to Nirmala Bonat. ${ }^{22}$

Another case on abuse is the case of Marni Anyim v. Shalini Shanmugam and Anor. ${ }^{23}$ In this case, the plaintiff, Marni Anyim was an Indonesian domestic helper employed by the second defendant. The first defendant was the wife of the second defendant. The plaintiff had suffered degradation, verbal and physical abuse along the course of her employment. She testified that she was forced to wear old undergarments by her employer. She was also placed a hot iron on her back, punched on the left side of the eyes, hammered on the head and was fed leftovers and dog food.

In some cases, the condition of migrant workers often amount to forced labour. For example, forced labour conditions are reported to occur in "palm oil and rubber plantations, factories manufacturing computer components, garment production, restaurants, and in domestic households". ${ }^{24}$ They are subjected to excessive working hours and conditions. For instance, in line at factories, they are standing for 8 to 12 hours while working without toilet breaks. Their accommodations are also in poor condition. ${ }^{25}$ According to Rahman ${ }^{26}$, among the forms of exploitation are low remuneration, no medical benefits, and physical abuse. Her survey also found that, 48 percent of the foreign workers respondent had to work between 1012 hours a day and 30 percent of them had to work more than 12 hours a day. This incidence shows the poor condition of migrant workers that seems no less than forced labour.

In one report by Human Rights Watch ${ }^{27}$ "[...] Chain Channi, a domestic worker who started work each day at 5:00 a.m. and was not able to go to sleep until 3:00 a.m., never got a chance to rest. She described her experience at her employer's house in Malaysia: "If I finished my job quickly, my boss made

The Equal Rights Trust, Loc. cit.

Ibid.

Case Yim Pek Ha vs Public Prosecutor, No.W-09-185-2009.

Case Nirmala Bonat v. Yim Pek Ha \& Anor, 2015, 4 CLJ 334.

Case Marni Anyim v. Shalini Shanmugam and Anor, 2006, 5 CLJ 330.

United States Department of State, "Country Reports on Human Rights Practices: Malaysia", http://www.state.gov/j/drl/rls/hrrpt/2010/ eap/154391.htm, accessed on 12 June 2016.

Amnesty International, Loc. cit.

Rozanah Ab Rahman, "Foreign Labour in Malaysia: Are They Protected by law?”, Current Law Journal, 1997.

Human Rights Watch, "Cambodia/Malaysia: Domestic Workers Face Abuse", http://www.hrw.org/news/2011/10/31/cambodia-malaysiadomestic-workers-face-abuse, accessed on 12 Juni/2016. 
me clean the house again. The wife of the employer shouted and beat me every day. She kicked [me], slapped me, pulled my hair and beat me all over my body... The employer also beat me with his hands and kicked me. I never received my salary."

These are among the crucial scenario of abuse and mistreatment by the employer happened in Malaysia. Having mentioned these however, not all migrant workers in Malaysia suffer abuse but few. Many of them still have positive employment experiences and always renew their contracts annually. This positive experience is due to the fact that they received well treatment from their employers like on time payment of salary, allowed them to have holidays as well as keep in touch with their families. ${ }^{28}$

\section{b. Discrimination by Enforcement and Recruitment Agencies}

It is also surprising that the cause of mistreatment against migrant workers are not only done by employers but also committed by the enforcement and recruitment agencies. Discrimination done by enforcement agencies are due to the fact that they are given powers and the powers has been abused by them during the handling of matters with the migrant workers. Over reliance on the recruitment agencies has also led to an abuse of the permission for them to recruit migrant workers where there are cases of mistreatment against migrant workers as well as the issue of human trafficking committed by the agencies.

These problems that encountered by the migrant workers are seemingly prompted from the flawed legal protection. The lacking in the legal protection is not due to the unavailability of the laws, but lack of efficient enforcement on the part of the enforcement agencies. There are numerous laws protecting the rights of workers in Malaysia, be it locals or migrant workers. For instance Employment Act 1955, Industrial Relation Act 1967, Minimum Wages Consultative Council 2011 and Minimum Wages Order 2012 and 2013. Whilst these Acts should be sufficient in protecting the rights of the migrant workers, they are limited and do not cover domestic workers.

As mentioned earlier, the problem of discrimination against migrant workers is perhaps due to over reliance on the recruitment agencies in handling the coming of the migrant workers. The recruitment agencies are the parties who promise everything under the sun to the potential workers, but later it turns out to be otherwise when the workers arrived to Malaysia. The abuse and mistreatment by the agencies are varies; for examples, no proper documentation for the registration of the workers which consequently make them illegal migrants, extreme high fees, retention of workers passport and improper housing conditions while waiting for placement.

Further, it is also found that the problem of discrimination encountered by the migrant workers comes from the enforcement agencies/bodies themselves. The Malaysian Immigration Department is the main authority responsible for enforcing immigration law in Malaysia. The department which is under the Ministry of Home Affairs serves the Malaysian citizens, permanent residents and foreign visitors, and also the responsible department enforcing the Immigration Act 1959/63 (Act 155), Immigration Regulations 1963 and Passport Act 1966 (Act 150). All of these Acts are the cornerstone of the Malaysian immigration system including specifying the requirements

28 John West, "Malaysia's Abuses of. migrants' rights", http://www.asiancenturyinstitute.com/migration/190-malaysia-s-abuses-of-migrantsrights, accessed on12 Juni 2014. 
to present passports on entering or leaving Malaysia, and possession of the relevant visas.

Apart from the Malaysian Immigration Department, the police force and the volunteer cops (Ikatan Relawan Rakyat - RELA) are the main enforcement bodies which have the power over the migrant workers. The power of police force is not only limited to policing duties but also including the prevention of illegal migrant workers and subversive movements. As prescribed by the Police Act 1967, it is the duties of the Royal Malaysian Police (RMP) is to maintain law and order, to preserve peace and security, to detect and prevent criminals, to arrest and prosecute the offenders and to accumulate security intelligence in Malaysia. ${ }^{29}$ Then, RELA was established in 1972 by virtue of the enforcement of (Essential Powers) Emergency Act 1964 - Essential Rules (Ikatan Relawan Rakyat) (Amendment) 2005. The establishment of RELA provides opportunities to the common people to be a member of a volunteer force. Like the RMP, RELA also has the duty to preserve and maintain the national peace and security of Malaysia.

In 2005, the Government of Malaysia then mandated RELA's volunteer to handle the issues of illegal migrant. This was provided under Section 2 of the (Essential Powers) Emergency Act 1964 where under this Act, the Essential Rules (Amendment) 2005) (Ikatan Relawan Rakyat) was consented by the King of Malaysia (Yang DiPertuan Agong). As mentioned earlier, this rule has given rtain powers to RELA Officers in tackling illegal migrant workers with effect on 1st February 2005. Apart from the Immigration Department, since the RMP and RELA have the power under the law to inspect the status of the migrant workers, extortion and ill-treatment are the main problem faced by migrant workers with these enforcement bodies. The migrant workers contended that they always become vulnerable targets by these two bodies, normally during stop and search procedure. ${ }^{30}$ After numerous reports made, the Government of Malaysia then stopped the use of RELA service in tackling the issue of migrant workers in the middle of 2009.

In general, Malaysia has a fairly complete system dealing with migrant workers. Despite that, large market pressures have prohibited the appropriate functioning of the system when the industry is still likely to exploit migrant workers. ${ }^{31}$ The weakness in the appropriate function of the system is nonetheless still apparent. On this point, further legal measures could probably be introduced to ensure a more efficient, transparent and human rights approach for the legal governance of foreign workers in Malaysia. ${ }^{32}$

\section{Perceptive Discrimination- Crimes Hike and Migrant Workers in Malaysia}

Perceptive discrimination is also a direct discrimination but others make unfair assumptions to the discriminated group due to their age, religion, disability, race, ethnicity, sexual orientation or marriage. ${ }^{33}$ The problems of perceptive discrimination are faced by migrant workers as they

29 Section 3(3) of the Police Act of Malaysia 1967.

30 Migrant workers are also harassed by RELA and other immigration authorities who regularly patrol in areas with a preponderance of migrant workers.

31 Vijayakumari Kanapathy, “Controlling Irregular Migration: The Malaysian Experience”, http://www.ilo.org/wcmsp5/groups/public/---asia/--ro-bangkok/documents/publication/wcms_160587.pdf, accessed on 20 April 2014.

32 Guru Dhillon, et.al, The Legal Governance On The Employment Of Foreign Workers In Malaysia, CLJ Bulletin, Vol 19, 2014.

33 Equality Law United Kingdom, “Types of Discrimination”, http://www.equality-law.co.uk/news/106/66/Types-of-discrimination-definitions/, accessed on 22 June 2015.

34 Ibid. 
are not citizens. They are seen as job snatchers, especially amongst the more impoverished group of workers, whether legal or illegal. ${ }^{34}$ This has led to discrimination in terms of negative perception towards migrant workers in relations to the crime index. Theoretically, there are several reasons to expect the relationship between migrant workers and crimes. According to economic theory of crime by Becker $^{35}$ and Ehrlich ${ }^{36}$, the migrant workers and natives have different legitimate earning opportunities, different probabilities of being convicted and different cost of conviction. LaLonde and Topel $^{37}$, and Borjas ${ }^{38}$ predicted that there will be a higher crime propensity when the migrant workers' experience worse labour market condition, as had happened in the United States. Borjas, Grogger and Hanson ${ }^{39}$ further argued that in the US case, the natives especially black males increased their criminal activities due to competition in the job market with the migrant workers. ${ }^{40}$

In Malaysia, there is no definite/extensive study on the relationship between immigration and crime hikes. However, it is perceived by many that some migrant workers, particularly the illegal ones, are engaged in criminal activities. ${ }^{41}$ Sidhu found that the number of crimes committed by migrants has increased three-fold from 1,333 in 1992 to 3,113 in $2002 .{ }^{42}$ While there is no direct evidence on the relationship between immigration and crime hikes in Malaysia, immigration issue may have the impact on the crime rates. A large number of literatures focus on the relationship between crime and unemployment; but results of these studies are still ambiguous. It is only suggested by a study that, for Malaysia, bad economic conditions cause crime in Malaysia. ${ }^{43}$ Moreover, immigration also claimed to affect the proneness to commit crimes. Sidhu ${ }^{44}$ referred to studies by Massari ${ }^{45}$ and Zaidi ${ }^{46}$ in various states of Malaysia in 2005 and highlighted that the number of crimes declined when the number of migrant workers increased in that particular state. ${ }^{47}$ Despite the findings of the above which was in 2005, is the current scenario change from the previous finding that the increase number migrant workers does not related to the increase of crime index?

The crime index as reported by the House of Parliament showed that the total number of crimes in Malaysia in 2013 is 111,020 cases and 153, 669 in 2012. The crime index in 2013 is lower compared to 2012. This can be seen in Figure 2 below.

\section{Chart 2. Crime Index in Malaysia in 2012 and} 2013

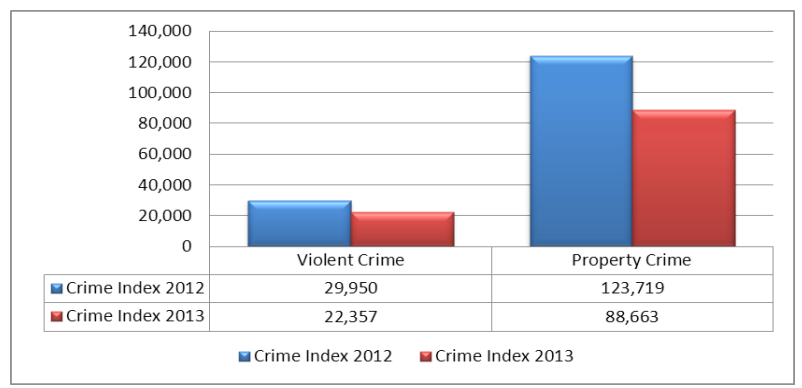

Source: Statistic from House of Parliament, 2013.

35 Gary S. Becker, "Crime and Punishment: An Economic Approach”, Journal of Political Economy. Vol.76, No. 2, 1968, p. 169.

36 Isaac Ehrlich, "Participation in Illegitimate Activities: A Theoretical and Empirical Inves-Tigation", Journal of Political Economy, Vol. 81, No. 3, 1973, p. 51 .

37 Robert J. La Londe and Robert H. Topel, "Immigrants in The American Labor Market: Quality, Assimilation, and Distributional Effects", The American Economic Review, Vol. 81, No.2, 1991, p. 297.

38 George J Borjas, "The Economic Progress of Immigrants", http://www.nber.org/papers/w6506, accessed on 20 April 2014.

39 George J Borjas, et al., "Immigration and the Economic Status of African $\square$ American Men”, Economica, Vol.77, No. 306, 2010 , p.255.

40 Milo Bianchi, et al., Loc. cit.

41 Amar Singh Sidhu, "The Rise of Crime in Malaysia: An Academic and Statistical Analysis", Journal of the Kuala Lumpur Royal Malaysia Police College, No. 4, 2005, p. 22.

$42 \quad$ Ibid., p. 23.

43 Ximena Del Carpio, et al., "Immigration in Malaysia: Assessment of its Economic Effects, and a Review of the Policy and System", http:// psu.um.edu.my/images/psu/doc/8\%20july\%20Internatinal\%20Conference,\%20migration,\%20urbanization\%20and\%20development/5-\%20 Extended\%20Abstract_Mauro\%20Testaverde_Malaysia\%20Migration\%20WB\%20Executive\%20Summary.pdf, accessed 30 Agustus 2014.

44 Amar Singh Sidhu, Loc. cit.

45 Massari Hashim, "Impak Pendatang Haram keatas Kejadian Jenayah - Satu Kajian dinegeri Johor", in Ibid.

46 Zaidi Morshidi, "Masalah Pendatang Asing Tanpa Izin ( PATI) dan Hubungannya dengan Jenayah", in Ibid.

47 Ibid. 
The Royal Malaysian Police categorised types of crimes into two: violent crime and property crime. ${ }^{48}$ Violent crime involves murder, rape, armed gang robbery, gang robbery, robbery and assault (Figure 3); while property crime deals with robbery, car theft, motorcycle theft, commercial vehicle theft, snatch theft and break in (Figure 4).

\section{Chart 3. Statistic of Violent Crime in Malaysia} in 2012 and 2013

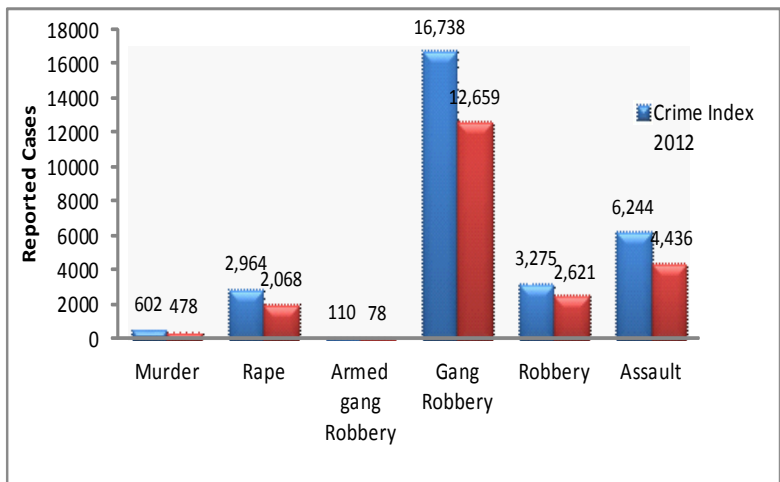

Source: Statistic from House of Parliament, 2013.

Figure 3 above and 4 below indicate the statistic of crimes committed by both citizen and non-citizen. Based on Figure 3, there is a steady decrease of violent crime in 2013 as compared to 2012.

\section{Chart 4. Statistic of Property Crime in Malaysia} in 2012 and 2013

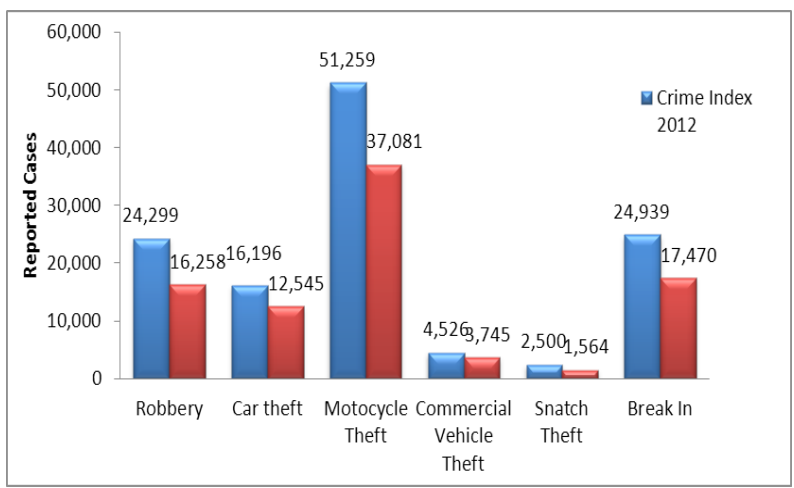

Source: Statistic from House of Parliament, 2013.
To further illustrate crimes committed by migrant workers, statistic in Figure 5 shows the crime index in 2012 and 2013 committed by migrant workers. This statistic resembles all crimes committed by non-citizen regardless their races and religious belief. The crimes by non-citizens were mainly committed by the Indonesians due to their larger number as compared to other nationalities. The number is about 62 percent of the total crimes. Despite that, the crimes committed by the migrant workers recorded only around 2 percent of the total index crimes in Malaysia. ${ }^{49}$ This statistic is still unchanged and revolving around 1-2 percent as mentioned by the Deputy Home Minister of Malaysia. ${ }^{50}$

\section{Chart 5. Statistic of Property Crime in Malaysia} in 2012 and 2013

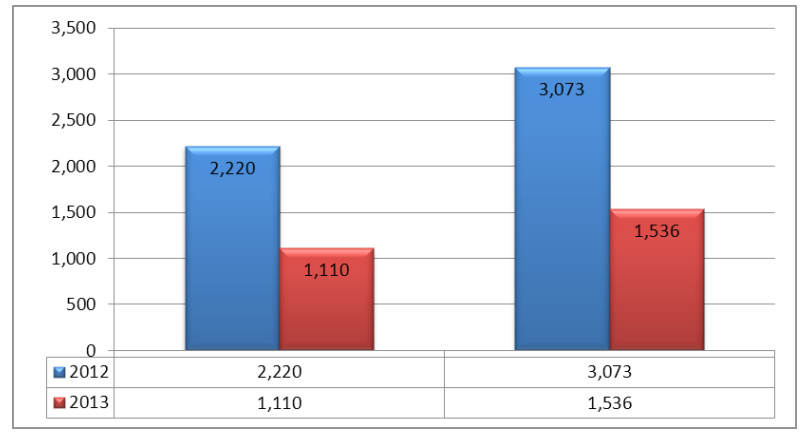

Source: Statistic from House of Parliament, 2013.

Currently, a growing concern is shown among Malaysian as regards to the crimes committed by the migrants from African nations. The statistics of violent crimes from 2009 to April 2014 show significant increases on the number of violent crimes committed by the Africans, particularly in 2014 (Figure 6). With regards to the property crimes, the trend is also worrying as the statistics also showed considerable increase of the commission of property crimes involving Africans (Figure 7).

\section{Ibid.}

Ibid., pp. 22-23.

50 Yuen Mei Keng, states that "Parliament: Only 1\% of crimes are committed by foreigners, says Wan Junaidi". See The Star, "Parliament Crime Ilegal Migrants", http://www.thestar.com.my/News/Nation/2013/07/09/Parliament-crime-illegal-migrants/. accessed on 30 Agustus 2014. 
Chart 6. Statistic of Violent Crime Commited by African in Malaysia in 2009-2014

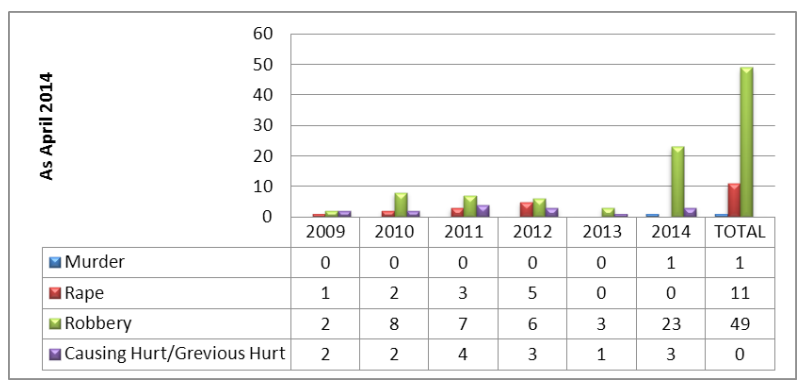

Source: Statistic from House of Parliament, 2014.

\section{Chart 7. Statistic of Property Crime Commited by African in Malaysia in 2009-2014}

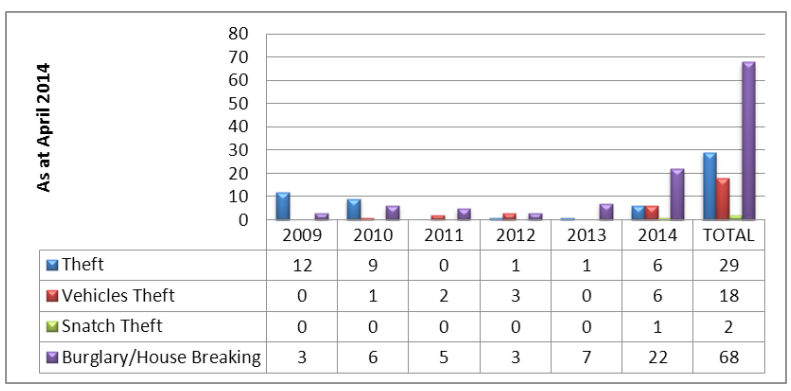

Source: Statistic from House of Parliament, 2014.

Based on the Figures above, it is submitted that migrant workers in Malaysia are subjected to "perspective discrimination" though they have the propensity to commit violent crime. ${ }^{51}$ Nevertheless, although the increase number of migrant workers did not affect significant increase of crime index, it is worrying that most violent crime and property crime $^{52}$ were committed by migrant workers ${ }^{53}$ and may cause public perception towards the enforcement agencies that there are insufficient measures taken by the enforcement agencies to curb the violent crimes committed by the migrant workers". ${ }^{54}$

It is thus submitted that foreign migrant workers though statistically contributing to only $2 \%$ of the total index crime they, when they do, nevertheless commit violent crimes and property crimes which are a cause for concern as it affects both the image of the police force as well as public safety in Malaysia. ${ }^{55}$

\section{Conclusion}

Based on the discussion above, the problem of discrimination against migrant workers in Malaysia may be classified into direct and perceptive discrimination. Direct discriminations are actually in the form of physical discrimination. The physical discriminations are mostly happened due to ineffective enforcement of the law to protect the migrant workers against ill-treatment, abuse of powers and the problem of human trafficking. It may also be concluded that the discrimination are done by the employer, enforcement as well as recruitment agencies.

With regards to discrimination committed by enforcement and recruitment agencies, some measures have been taken by the Government of Malaysia to address the issues like the withdrawal of RELA powers upon migrant workers and the introduction of several laws, for instance AntiTrafficking in Persons Act 2007, Minimum Wages Consultative Council Act 2011 and Minimum Wages Order 2012. These measures show the commitment by the Government of Malaysia to curb the problem of discrimination against migrant workers in Malaysia. However, the effectiveness on the enforcement of these laws is yet to be seen.

In relation to discrimination against migrant workers by the employer, certain measures are suggested to be taken by the Government of Malaysia to tackle the problem. Since the domestic workers are not protected under the current labour laws in Malaysia, it is suggested that Malaysia ratifies the ILO Convention on Domestic Worker and International Labour Organization Convention on Domestic Work. These conventions require the government to guarantee decent working conditions,

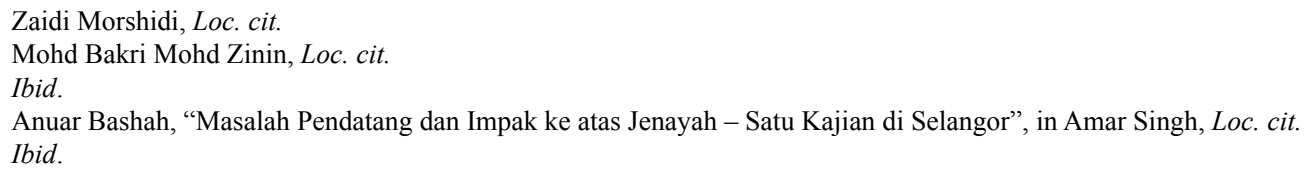


to impose a minimum age requirement for domestic workers, and to protect domestic workers from violence and exploitative recruitment practices. The migrant workers are still outside the purview of Minimum Wages Order 2012. The Minimum Wages Order 2012 does not apply to apprentices nor to domestic servants as defined under Section 2 of the Employment Act 1955 and this provision should be amended to include the migrant workers. Minimum Wages Policy has raised the basic wages of all employees to a minimum of RM900 in Peninsular Malaysia and RM800 in Sabah, Sarawak and Labuan respectively. It is recommended that this Minimum Wages Policy be made applicable to migrant workers as well. Thus, the move is believed will reduce the issue of discriminations against migrant workers.

This article also highlights the problem of perceptive discrimination against migrant workers that the crime hike in Malaysia is due to the influx of migrant workers into Malaysia. This study found that the claim is unsupported based on the statistics given by the Royal Malaysian Police. It is proposed that the problem of perceptive discrimination against migrant workers to be undertaken by declassifying the report on crime index in Malaysia. In other words, the detail data and statistic on crime index in Malaysia should be made available online to public. $^{56}$

To sum up, it is timely for Malaysia to introduce a comprehensive migration law, strengthen the monitoring of recruitment agencies, and impose significant penalties when violations occur against migrant workers. More importantly, effective enforcement is needed from the relevant enforcement departments. The Malaysian government should also provide proper legal recourse and support services for abused migrant workers which include legal aid and psychological services. Currently, the only well-known NGO in Malaysia that provides the help and services to migrant worker is TENAGANITA. Malaysia has introduced a special court to deal with migrants $;{ }^{57}$ however, the court should not look into the cases of breaching the immigration law only, but also any breach of human rights or basic rights of the migrants and migrant workers as well.

\section{REFERENCES}

\section{A. Books}

Amnesty International, 2010, Trapped: The Exploitation of Migrant Workers in Malaysia, Amnesty International Publication, London.

Dobinson, Ian and Johns, Francis, 2007, Qualitative legal research, Edinburgh University Press, Edinburgh.

Salter, Michael and Mason, Julie, 2007, Writing law Dissertations: An Introduction and Guide to The Conduct of Legal Research, Pearson Education, London.

\section{B. Anthologies}

Pappusamy, P. Iruthayaraj D., "Impact of Foreign
Labour on Industry", in Cyrus Das, Employment and Industrial Relations Law in Malaysia, 2014, CLJ Publication, Ampang.

\section{Journal Articles}

Becker, Gary S., "Crime and Punishment: An Economic Approach", Journal of Political Economy. Vol.76, No. 2, 1968.

Bianchi, Milo, et al., "Do Immigrants Cause Crime?" Journal of the European Economic Association Vol.10, Issue. 6, 2012.

Borjas, George J, et al., "Immigration and the Economic Status of African American Men", Economica, Vol.77, No. 306, 2010.

\footnotetext{
Currently, the crime statistics is only available upon request for research purposes or when the data is required by the Parliament. Cyrus Das, "Special Courts to Deal with Illegal Immigrants", http://www.malaysianbar.org.my/press_statements/special_courts_to_deal_ with_illegal_immigrants.html, accessed on 30 Agustus 2014.
} 
Dhillon, Guru, et.al, The Legal Governance On The Employment Of Foreign Workers In Malaysia, CLJ Bulletin, Vol 19, 2014.

Ehrlich, Isaac, "Participation in Illegitimate Activities: A Theoretical and Empirical Investigation", Journal of Political Economy, Vol. 81, No. 3, 1973.

Londe, Robert J. La and Topel, Robert H., "Immigrants in The American Labor Market: Quality, Assimilation, and Distributional Effects", The American Economic Review, Vol. 81, No.2, 1991.

Rahman, Rozanah Ab, "Foreign Labour in Malaysia: Are They Protected by law?", Current Law Journal, 1997.

Sidhu, Amar Singh, "The Rise of Crime in Malaysia: An Academic and Statistical Analysis", Journal of the Kuala Lumpur Royal Malaysia Police College, No. 4, 2005.

Soylu, Ali and Buchanan, Tom A., "Ethnic and Racial Discrimination Against Immigrants", Journal of Business and Economics, Vol. 4, No. 9, 2013.

\section{Internet Articles}

Borjas, George J., "The Economic Progress of Immigrants", http://www.nber.org/papers/ w6506, accessed on 20 April 2014.

Chan, Ngai Weng, et al., "Integrating Official And Traditional Flood Hazard Management In Malaysia”, http://eprints.usm.my/1198/1/ Integrating_Official_And_Traditional_ Flood_Hazard_management_In_Malaysia. $p d f$, accessed on 13 June 2014.

Carpio, Ximena Del, et al., "Immigration in Malaysia:Assessment of its Economic Effects, and a Review of the Policy and System", http://psu.um.edu.my/images/psu/doc/8\%20 july\%20Internatinal\%20Conference, $\% 20$ migration,\%20urbanization\%20and\%20 development $/ 5-\% 20$ Extended\%20Abstract Mauro\%20Testaverde_Malaysia\%20 Migration\%20WB\%20Executive\%20 Summary.pdf, accessed 30 Agustus 2014.
Das, Cyrus, "Special Courts to Deal with Illegal Immigrants", http://www.malaysianbar.org. my/press_statements/special_courts_to_ deal_with_illegal_immigrants.html, accessed on 30 Agustus 2014.

Equal Rights Trust, "Washing the Tigers Addressing Discrimination and Inequality in Malaysia", http://www.equalrightstrust.org/ ertdocumentbank/Malaysia\%20CR\%201. $p d f$, accessed on 13 June 2014.

Equality Law United Kingdom, "Types of Discrimination", http://www.equality-law.co.uk/ news/106/66/Types-of-discriminationdefinitions/, accessed on 22 June 2015.

Human Rights Watch, "Cambodia/Malaysia: Domestic Workers Face Abuse", http:// www.hrw.org/news/2011/10/31/cambodiamalaysia-domestic-workers-face-abuse, accessed on 12 Juni/2016.

Imigration Assist United Kingdom, "What is An Immigrant", http://www.immigrationassist. co.uk/immigration/what-is-an-immigrant/, accessed on 20 April 2014.

Kanapathy, Vijayakumari, "Controlling Irregular Migration: The Malaysian Experience", http://www.ilo.org/wcmsp5/groups/public/--asia/---ro-bangkok/documents/publication/ wcms_160587.pdf, accessed on 20 April 2014.

Migration Watch United Kingdom, "How Immigration is Measured", http://www. migrationwatchuk.org/briefingPaper/ document/95, accessed on 13 June 2014.

Piper, Nicola, "Migrant Labor in Southeast Asia", $\quad \mathrm{h} t t p: / / w w w . f e s . d e / a k t u e l l / f o c u s$ interkulturelles/focus_1/documents/8_000. $p d f$, accessed on 13 June 2014.

Tactaquin, Catherine, "Immigration and Globalization: The UN Conference Against Racism Takes on Migrant Issues", http://www. corpwatch.org/article.php?id=375, accessed on 20 April 2014.

The Star, "Parliament Crime Ilegal Migrants", http://www.thestar.com. my/News/ 
Nation/2013/07/09/Parliament-crimeillegal-migrants/. accessed on 30 Agustus 2014.

The United Nations, "United Nations Human Rights: Combating Discrimination against Migrants", http://www.ohchr.org/EN/Issues/ Discrimination/Pages/discrimination migrants.aspx, accessed on 20 April 2014.

The United Nations. United Nations Human Rights: Combating Discrimination against Migrants, http://www.ohchr.org/EN/Issues/ Discrimination/Pages/discrimination migrants.aspx, accessed on 12 June 2014.

United States Department of State, "Country Reports on Human Rights Practices: Malaysia", http://www.state.gov/j/drl/rls/hrrpt/2010/ eap/154391.htm, accessed on 12 June 2016.

Ximena Del Carpio, et.al., "Immigration in Malaysia: Assessment of its Economic Effects, and a Review of The Policy and
System", $\quad$ http://psu.um.edu.my/images/ psu/doc/Recommended\%20Reading/ Immigration\%20in\%20Malaysia.pdf, accessed on 13 June 2014.

West, John "Malaysia's Abuses of. migrants' rights", http://www.asiancenturyinstitute. com/migration/190-malaysia-s-abuses-ofmigrants-rights, accessed on12 Juni 2014.

\section{E. Regulations}

The Declaration of Principles on Equality.

Police Act of Malaysia 1967.

\section{F. Cases}

Case Yim Pek Ha vs Public Prosecutor, No.W-09185-2009.

Case Nirmala Bonat v. Yim Pek Ha \& Anor, 2015, 4 CLJ 334.

Case Marni Anyim v. Shalini Shanmugam and Anor, 2006, 5 CLJ 330. 